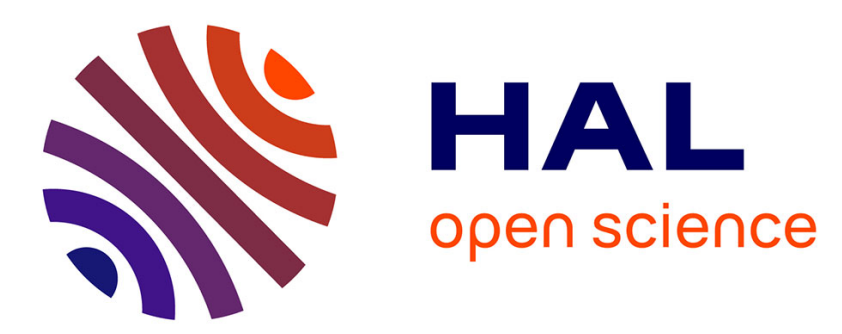

\title{
Structural and Vibrational Study of CsSbGe3O9, a New Germanate in the ASbGe3O9 Family (A = Alkali Metal)
}

Monique Tillard, Abel Haidoux, Dominique Granier, Léa Daenens, Pascale Armand

\section{- To cite this version:}

Monique Tillard, Abel Haidoux, Dominique Granier, Léa Daenens, Pascale Armand. Structural and Vibrational Study of CsSbGe3O9, a New Germanate in the ASbGe3O9 Family (A = Alkali Metal). Inorganic Chemistry, 2021, 60 (14), pp.10361 - 10370. 10.1021/acs.inorgchem.1c00747 . hal-03293686

\section{HAL Id: hal-03293686 \\ https://hal.science/hal-03293686}

Submitted on 23 Aug 2021

HAL is a multi-disciplinary open access archive for the deposit and dissemination of scientific research documents, whether they are published or not. The documents may come from teaching and research institutions in France or abroad, or from public or private research centers.
L'archive ouverte pluridisciplinaire HAL, est destinée au dépôt et à la diffusion de documents scientifiques de niveau recherche, publiés ou non, émanant des établissements d'enseignement et de recherche français ou étrangers, des laboratoires publics ou privés. 


\section{Structural and vibrational study of $\mathrm{CsSbGe}_{3} \mathrm{O}_{9}$, a new germanate in the $A \mathrm{SbGe}_{3} \mathrm{O}_{9}$ family $(A=$ alkali metal $)$.}

Monique Tillard ${ }^{\circ}$, Abel Haidoux, Dominique Granier,

Léa Daenens, Pascale Armand*, o

ICGM, Univ. Montpellier, CNRS, ENSCM, Montpellier, France

Corresponding author

*E-mail: pascale.armand @umontpellier.fr ; Tel: +33 (0)4 67143319

${ }^{\circ}$ ORCID: P. Armand 0000-0001-8921-5427, M. Tillard 0000-0002-0609-7224 


\section{Abstract:}

The germanate $\mathrm{CsSbGe}_{3} \mathrm{O}_{9}$, grown spontaneously via the high-temperature solution method from $\mathrm{Cs}_{2} \mathrm{Mo}_{4} \mathrm{O}_{13}$ used as a flux, crystallizes in the orthorhombic system $a=12.3636(2), b=$ 13.8521(2), $c=31.4824(5) \AA, V=5391.73(2) \AA^{3}$. Its structure, determined from single-crystal X-ray diffraction data, is most probably non-centrosymmetric despite our choice to report it in the centro-symmetric maximal supergroup Pnma $D_{2 h}^{16}\left(n^{\circ} 62\right)$ in which agreement factors $R 1=$ 0.0371 and $\mathrm{w} R 2=0.0706$ (all data) were obtained. The unit cell contains 24 formulas $\mathrm{CsSbGe}_{3} \mathrm{O}_{9}$. The 3-dimensional network is built up with regular germanate tetrahedra at nine crystallographically independent $\mathrm{Ge}$ sites. The $\mathrm{Sb}$ atoms (four independent positions) adopt octahedral coordination with $\mathrm{O}$ atoms and the $\mathrm{Cs}^{+}$cations are located in the channels of the 3-D network. A more in-depth analysis of the structure of $\mathrm{CsSbGe}_{3} \mathrm{O}_{9}$ is carried out in the light of the structures previously determined for the compounds $A \operatorname{SbGe}_{3} \mathrm{O}_{9}(A=\mathrm{K}, \mathrm{Rb})$ having the same chemical formula but significantly different atomic arrangements. The structural characteristics are discussed related to literature and the nature of the monovalent cation $A^{+}$.

KEYWORDS: oxides, crystal growth, X-ray diffraction, Raman spectroscopy, crystal structure 


\section{Introduction}

In our search for new oxide materials with a non-centrosymmetric structure for piezoelectric and non-linear optical applications, we took an interest first in the germanium dioxide $\mathrm{GeO}_{2}$ which adopts $\alpha$-quartz-like structure and later in some ternary oxides ${ }^{1-4}$. The ternary phases $A \mathrm{SbGe}_{3} \mathrm{O}_{9}$ with $A=\mathrm{K}, \mathrm{Rb}$ display a structural relationship with the Benitoite-type structure associated with the mineral $\mathrm{BaTiSi}_{3} \mathrm{O}_{9}{ }^{5-7}$. The $A \mathrm{BX}_{3} \mathrm{O}_{9}$ ternary oxides of Benitoite-type are made up of $\mathrm{X}_{3} \mathrm{O}_{9}$ cyclic units with $\mathrm{X}=\mathrm{Si}$, Ge. They include a post-transition or main group element B that can easily adopt octahedral coordination such as $\mathrm{Ti}, \mathrm{Ge}, \mathrm{Sn}, \mathrm{Ta} .$. and a large mono or divalent cation taken from alkaline or alkaline earth as $\mathrm{K}, \mathrm{Rb}, \mathrm{Ba}$, or even $\mathrm{Tl}$ (8-12). Synthetic germanates isostructural with the natural Benitoite $\mathrm{BaTiSi}_{3} \mathrm{O}_{9}(P \overline{\mathbf{6}} c 2$ space group $)$ are few to be reported in the literature $5,13,14$.

In earlier crystallographic works dealing with X-ray diffraction studies of flux-grown singlecrystals, we have shown that $\mathrm{KSbGe}_{3} \mathrm{O}_{9}$ is isostructural to Benitoite while, despite many similarities, the compound $\mathrm{RbSbGe}_{3} \mathrm{O}_{9}$ is not isostructural ${ }^{5,6}$. In this context, it seemed very attractive to establish the crystal structure of $\mathrm{CsSbGe}_{3} \mathrm{O}_{9}$, hitherto unknown. This is the first reason why attempts have been made to synthesize this phase by the same slow cooling method using the flux technique. Besides, having good quality crystals is also useful to explore the vibrational characteristics and, in this particular case, to complement the study of the oxides of the $A \mathrm{SbGe}_{3} \mathrm{O}_{9}$ series with $A=\mathrm{K}, \mathrm{Rb}, \mathrm{Cs}$ and assess the role played by the monovalent cation $A^{+}$in this family of structures.

This paper presents the synthesis of sub-millimeter-sized crystals having the chemical composition $\mathrm{CsSbGe}_{3} \mathrm{O}_{9}$, the X-ray crystal structure determination, and a study of their optical properties in the visible range through IR and Raman spectroscopy. The crystallographic and vibrational experimental data are analyzed comparatively to those 
already obtained for $\mathrm{KSbGe}_{3} \mathrm{O}_{9}$ and $\mathrm{RbSbGe}_{3} \mathrm{O}_{9}$ with the idea of better understand how the identity of the alkaline element may influence the compound formation and crystallization.

\section{Experimental section}

The high-temperature flux technique with the slow cooling crystal growth method was used to spontaneously nucleate crystals of $\mathrm{CsSbGe}_{3} \mathrm{O}_{9}$ using $\mathrm{Cs}_{2} \mathrm{Mo}_{4} \mathrm{O}_{13}$ as a flux. The starting reagents were commercial Alfa Aesar products $\mathrm{MoO}_{3}(99.95 \%), \mathrm{Cs}_{2} \mathrm{CO}_{3}(99 \%)$, and $\mathrm{Yb}_{2} \mathrm{O}_{3}$ (99.9\%). They were used as received. The flux $\mathrm{Cs}_{2} \mathrm{Mo}_{4} \mathrm{O}_{13}(100 \mathrm{~g})$ was prepared from powders $\mathrm{Cs}_{2} \mathrm{CO}_{3}(38.5 \mathrm{~g})$ and $\mathrm{MoO}_{3}(67.1 \mathrm{~g})$ via a solid-state reaction at $465^{\circ} \mathrm{C}$ for two weeks. A total amount of $15 \mathrm{~g}$ of an intimate mixture of $3 \mathrm{~g}$ of $\mathrm{Yb}_{2} \mathrm{O}_{3}$ and $12 \mathrm{~g}$ of $\mathrm{Cs}_{2} \mathrm{Mo}_{4} \mathrm{O}_{13}$ in a weight ratio of 20/80 was added in a $5 \mathrm{~cm}^{3} \mathrm{Pt}$ crucible with a lid. The crucible was placed in an electrical furnace and heated at $970{ }^{\circ} \mathrm{C}$ in the air for 6 hours to ensure the complete dissolution of the solute. Then, the temperature was slowly lowered at a rate of $1 \%$ h down to $745^{\circ} \mathrm{C}$ for crystal growth, then the furnace was turned off.

The compound was characterized using differential scanning calorimetry (DSC), powder Xray diffraction (XRD), and room-temperature infrared and non-polarized Raman spectroscopy. Details on the experimental procedures can be found in a previous paper ${ }^{6}$.

The analysis by Energy Dispersive X-ray (EDX) spectroscopy of the grown crystals, using an Electron Scanning Environmental Microscope (ESEM) equipped with an Inca micro analyzer (Oxford Instruments), determined the content of $\mathrm{Cs}, \mathrm{Ge}$, and $\mathrm{Sb}$ elements. Three independent measures were made at the surface of the same as-grown crystal in order to check the homogeneity of the results.

Crystals with suitable quality and size were selected for X-ray diffraction experiments on a Bruker D8 Venture diffractometer (Mo micro source and Photon II CPAD detector). The data 
collected were handled with the Apex suite ${ }^{15}$ and the structural solutions searched and refined with the SHELX programs ${ }^{16,17}$.

\section{Results}

\subsection{Compound characterization.}

The visually colorless and transparent platelets with sub-millimeter sizes that were obtained from the melt have hexagonal shapes and sharp edges. Their chemical EDX analysis gave atomic concentrations of $6.8 \pm 0.2$ at. $\%$ for $\mathrm{Sb}, 6.9 \pm 0.2$ at.\% for $\mathrm{Cs}$, and $21.1 \pm 0.2$ at.\% for Ge. With a Cs:Sb:Ge ratio of 1:1:3, the nominal composition is $\mathrm{CsSbGe}_{3} \mathrm{O}_{9}$. No phase transition was observed during the DSC experiment where $44.3 \mathrm{mg}$ of crystals were heated from room temperature, at a heating rate of $5 \% \mathrm{~min}$, up to $1200{ }^{\circ} \mathrm{C}$. The melting point was detected at $1080 \pm 1{ }^{\circ} \mathrm{C}$, which indicates good thermal stability of the material in a large range of temperatures.

The room temperature XRD pattern recorded for a powdered sample of $\mathrm{CsSbGe}_{3} \mathrm{O}_{9}$ is rather complex and does not match any reference in the X'Pert HighScore database ${ }^{18}$.

\subsection{Structure determination.}

Two as-grown crystals, selected under polarized light for singularity, were used in this structural study. For each of them, the diffracted data are complex, and indexing the reciprocal lattice was not obvious. In the first stages, taking into account only the "main" diffraction spots allowed an indexation of the data with orthogonal axes $a=12.4, \mathrm{~b}=13.8, c$ $=5.2 \AA$. Such data processing only led to incomplete/incoherent structural models from which no satisfactory refinement could be achieved. Subsequently, a new indexation was carried out by taking into account all the diffraction spots, which required to multiply by 6 the $c$ parameter. Thus, the data sets were indexed within an orthorhombic lattice of parameters $a=$ 12.3636(2), $b=13.8521(2), c=31.4824(5) \AA$ (crystal 1) and $a=12.3813(3), b=13.8699(5)$, 
$c=31.5109(8) \AA$ (crystal 2). Using these lattice dimensions and symmetry, a very good profile fitting was obtained for the XRD powder pattern recorded at room temperature in standard conditions (PANalytical X'Pert Pro II diffractometer, $\mathrm{Cu} \mathrm{K} \alpha$ radiation, $10-50^{\circ}$ angular $2 \theta$ range) for the $\mathrm{CsSbGe}_{3} \mathrm{O}_{9}$ compound. The main parameters, related to the recording of diffraction data and the refinement of the structural model, are collected in Table 1.

Table 1. Crystal data and structure refinement parameters for $\mathrm{CsSbGe}_{3} \mathrm{O}_{9}$.

System

Space group

Temperature, $\mathrm{K}$

Unit cell dimensions, $\AA$

Volume, $\AA^{3}$

$\mathrm{Z}$

Calculated density, $\mathrm{Mg} / \mathrm{m}^{3}$

$\mathrm{F}(000)$

Diffractometer, source

Radiation, wavelength $(\AA)$

Absorption coefficient, $\mathrm{mm}^{-1}$

Absorption correction

Crystal size, $\mathrm{mm}$

Theta range, ${ }^{\circ}$

Index ranges

Reflections collected

Independent reflections

Refinement type

Goodness-of-fit on $\mathrm{F}^{2}$

Final $R 1(\mathrm{I}>2 \sigma(\mathrm{I}))$

$$
\mathrm{w} R 2(\mathrm{I}>2 \sigma(\mathrm{I}))
$$

$R 1, w R 2$ indices (all data)

Extinction coefficient

Fourier residuals $\Delta \rho$, e. $\AA^{-3}$
Orthorhombic

Pnma (n ${ }^{\circ}$ 62)

298(2)

$$
\begin{array}{ll}
a=12.3636(2) & a=12.3813(3) \\
b=13.8521(2) & b=13.8699(5) \\
c=31.4824(5) & c=31.5109(8)
\end{array}
$$

5391.73(2)

5411.3(3)

24

4.556

6576

Bruker D8 Venture, X-rays

$\mathrm{K} \alpha \mathrm{Mo}, 0.7107$

16.929

multi-scan SADABS

$$
\begin{array}{cc}
0.127 \times 0.069 \times 0.037 & 0.131 \times 0.088 \times 0.067 \\
2.095-31.000 & 2.092-31.000 \\
-17 \leq h \leq 17,-20 \leq k \leq 20,-45 \leq l \leq 45 \\
107272 & 138961
\end{array}
$$

$8882\left(\mathrm{R}_{\mathrm{int}}=0.0295\right)$

$8908\left(\mathrm{R}_{\text {int }}=0.0330\right)$

full-matrix least-squares on $\mathrm{F}^{2}$

$\begin{array}{cc}1.106 & 1.029 \\ 0.0324 & 0.0198 \\ 0.0687 & 0.0449\end{array}$

$0.0371,0.0706$

$0.0237,0.0462$

$0.00076(2)$

$0.000311(6)$

$3.204 /-3.747$ 
Several orthorhombic space groups were considered to find the structural solution. The extinction conditions identified in the two recorded crystal data sets $(0 k l, k+l=2 n+1$ and $h k 0$, $h=2 n+1)$ are fully compatible with Pnma (n ${ }^{\circ}$ 62) and Pna $2_{1}\left(\mathrm{n}^{\circ} 33\right)$ space groups. Nevertheless, the structure solution was also searched within other space groups as $P m n 2_{1}$ (31), $P m c 2_{1}$ (26), and $P 2_{1} 2_{1} 2_{1}$ (19) in which extinction conditions are less severe. After the data have been corrected for the effects of absorption, the refinement of the structural solutions in each of these groups was carried out to fairly good $R l$ values close to $3.5 \%$. Note that anisotropic displacement parameters have been refined for all the atoms.

For both sets of data, the structural refinement within the space groups Pnma ( $a b c$ setting), $P m n 2_{1}$ (b a $\quad \bar{c}$ setting) and $P m c 2_{1}$ (b c c a setting) was slightly better than in $P n a 2_{1}(\bar{a} c \quad b$ setting) and $P 22_{1} 2_{1} 2_{1} \quad(a b c$ setting). Refinement of the structural model within the centrosymmetric Pnma space group converged to R1 factors of 3.26 (crystal 1) and $3.54 \%$ (crystal 2) but residual density peaks of somewhat high intensity $\left(\sim 6.3-6.7 \mathrm{e} / \AA^{3}\right)$ are observed very close to the heaviest atoms. Very similar characteristics were observed for the refinements in the space groups $P n a 2_{1}$ and $P 2{ }_{1} 2_{1} 2_{1}$ but these residuals are significantly reduced, to about $3 \mathrm{e} / \AA^{3}$, when the resolution limit is changed to $\theta \leq 32$. With the only extinction conditions $h 00, h=2 n+1,0 k 0, k=2 n+1$ and $00 l, l=2 n+1$, the space group $P 2{ }_{1} 2_{1} 2_{1}$ could be dismissed.

On the other hand, slightly weaker residual peaks $\left(3.8-5.1 \mathrm{e} / \AA^{3}\right)$ were found near the Cs positions in the density difference maps when the structure is refined in the noncentrosymmetric space groups $P m n 2_{1}$ and $P m c 2_{1}$ leading to $R 1$ factors in the range 3.43 $3.56 \%$. Thus, if we consider the best density residuals and the best reliability factors, and even if it is impossible to exclude the other space groups, the quality of the refinements (standard deviations on the parameters of the atom ...) would also be in favor of these two space groups which seem the most likely for the compound. All these results tend to indicate non- 
centrosymmetry for the structure of $\mathrm{CsSbGe}_{3} \mathrm{O}_{9}$. Yet, the careful inspection of statistical tests on diffracted intensities, in which the heavy atoms contribute to most, shows a trend but does not provide clear evidence of an inversion center. Moreover, the Flack parameter which refines to values close to 0.5 could indicate an inversion twinning leading then to the centrosymmetric Pnma space group. Under these conditions, it is quite hard to decide and state what is the true symmetry and the space group to assign to the structure. Finally, because we cannot unequivocally attest to the lack of inversion center in $\mathrm{CsSbGe}_{3} \mathrm{O}_{9}$ and we want to avoid a bad choice of space group, we decide deliberately to give its structural description in the centrosymmetric space group Pnma (n $\left.{ }^{\circ} 62\right)$.

The results of the refinement in this space group, using the data sets collected for each of the two crystals, are available at the Cambridge Crystallographic Data Center ${ }^{19}$. The corresponding CIF files can be obtained indicating the following numbers: CSD 2068035 for crystal $1(a=12.3636, b=13.8521, c=31.4824 \AA)$ and CSD 2068034 for crystal $2(a=$ $12.3813, b=13.8699, c=31.5109 \AA)$.

\subsection{Structural description.}

The structural model is built up with 49 crystallographically independent atoms of which four

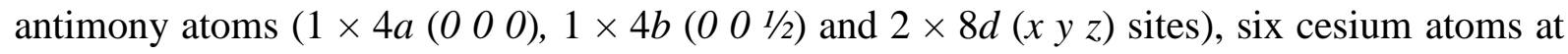
$4 c\left(x \frac{1}{4} / 4\right)$ sites, nine germanium atoms at $8 d$ general sites and 30 oxygen atoms $(6 \times 4 c$ and $24 \times 8 d$ sites). The orthorhombic unit cell contains 336 atoms, which corresponds to 24 units of formula $\mathrm{CsSbGe}_{3} \mathrm{O}_{9}$ and agrees with the EDX measurements performed on the crystals. The structure representation given in Figure 1 has been drawn using the program Diamond ${ }^{20}$. It shows that the $\mathrm{CsSbGe}_{3} \mathrm{O}_{9}$ structure consists of a three-dimensional arrangement of polyhedra $\mathrm{SbO}_{6}$ and $\mathrm{GeO}_{4}$, in which three-dimensional channels host the $\mathrm{Cs}^{+}$cations.

The four independent $\mathrm{Sb}^{V}$ atoms of the unit cell are 6-fold coordinated through $\mathrm{Sb}-\mathrm{O}$ bonds in the range 1.953 to $1.972 \AA$, Table 2 . The average of the six $\mathrm{Sb}-\mathrm{O}$ distances of an octahedron 
only varies from 1.963 to $1.966 \AA$ for the four $\mathrm{SbO}_{6}$ units. The $\mathrm{O}-\mathrm{Sb}-\mathrm{O}$ angle values, in the range $177.8-180.0^{\circ}$ (trans) and $84.2-96.2^{\circ}$ (cis), give a measure of the distortion from the ideal octahedral geometry with point group $\mathrm{O}_{\mathrm{h}}$. Each $\mathrm{SbO}_{6}$ octahedron shares all its vertices with six $\mathrm{GeO}_{4}$ tetrahedra, Figure 1.

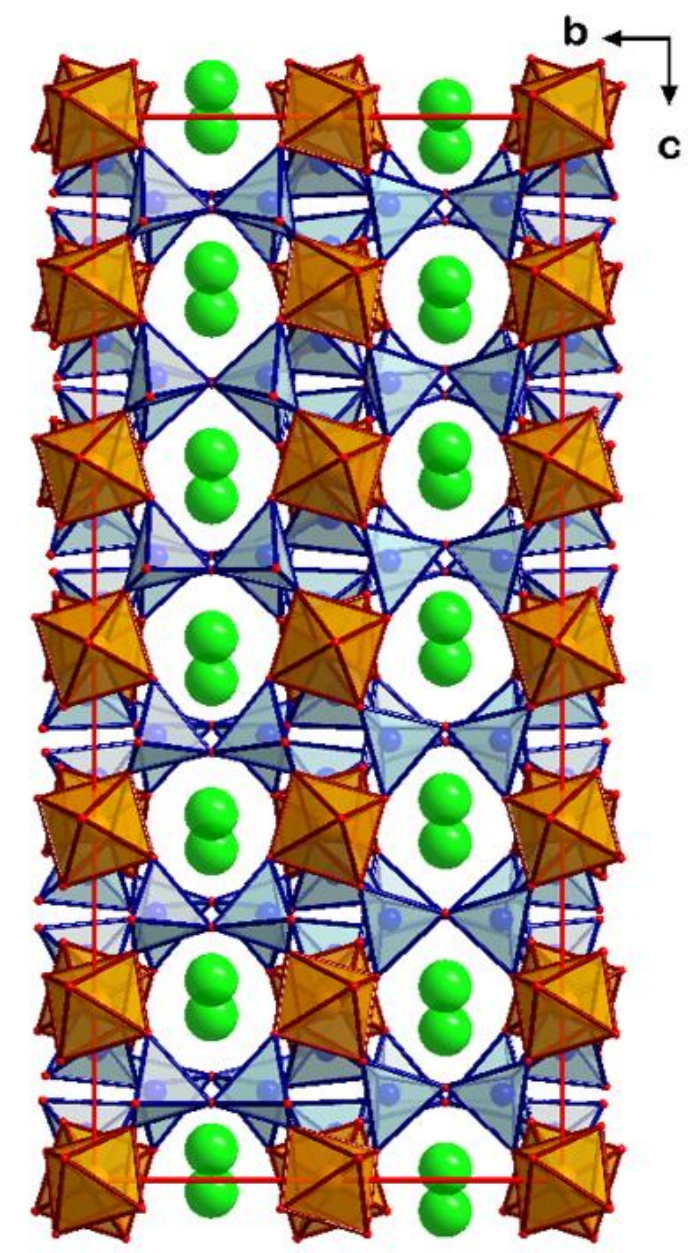

$\boldsymbol{a}$

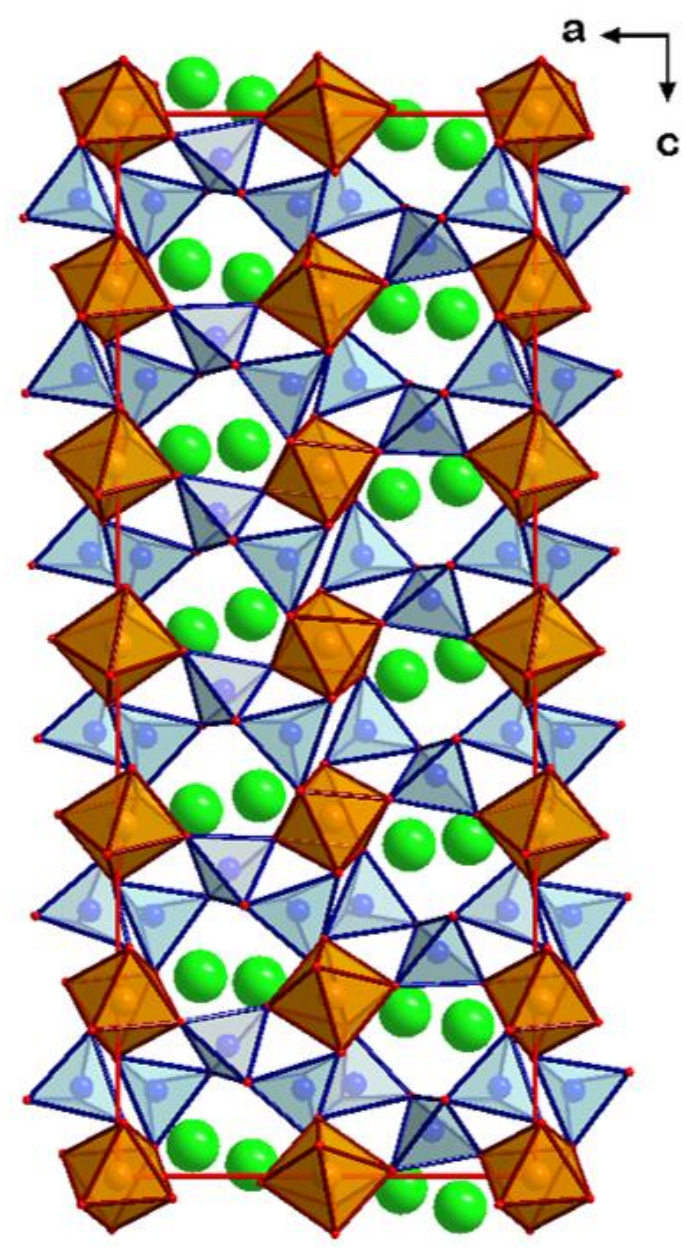

b

Figure 1. The orthorhombic structure of $\mathrm{CsSbGe}_{3} \mathrm{O}_{9}$ projected on $\boldsymbol{a}$ - the $(011)$ plane, $\boldsymbol{b}$ - the (101) plane, see Figure $8 \mathrm{~g}$ for the (110) projection. The $\mathrm{SbO}_{6}$ octahedra (brown) are interconnected through $\mathrm{GeO}_{4}$ tetrahedra (blue) within a 3-D framework. The $\mathrm{Cs}^{+}$cations are drawn as green spheres. 
The 4-fold coordinated germanium $\mathrm{Ge}^{I V}$ atoms (9 independent atoms) are involved in $\mathrm{Ge}-\mathrm{O}$ bonds ranging from 1.724 to $1.766 \AA$ within more or less regular $\mathrm{GeO}_{4}$ tetrahedral units (1.738 - $1.745 \AA$ for the average of $\mathrm{Ge}-\mathrm{O}$ distances within a tetrahedron), Table 2. Each $\mathrm{GeO}_{4}$ tetrahedron shares its vertices with two $\mathrm{GeO}_{4}$ and two $\mathrm{SbO}_{6}$ units, Figure 1.

Table 2. Main bond lengths $(\AA)$ for $\mathrm{CsSbGe}_{3} \mathrm{O}_{9}$.

\begin{tabular}{|c|c|c|c|c|c|c|c|c|}
\hline \multirow[t]{4}{*}{$\overline{S b 1}$} & $2 \times 08$ & $1.965(2)$ & $\mathrm{Sb} 3$ & $\mathrm{O} 20$ & $1.953(2)$ & $\mathrm{Sb} 4$ & $\mathrm{O} 12$ & $1.961(2)$ \\
\hline & $2 \times 06$ & $1.968(2)$ & & $\mathrm{O} 4$ & $1.958(2)$ & & O9 & $1.961(2)$ \\
\hline & $2 \times \mathrm{O} 3$ & $1.969(2)$ & & $\mathrm{O} 15$ & $1.964(2)$ & & $\mathrm{O} 24$ & $1.965(2)$ \\
\hline & & & & $\mathrm{O} 1$ & $1.970(2)$ & & O19 & $1.968(2)$ \\
\hline \multirow[t]{4}{*}{$\mathrm{Sb} 2$} & $2 \times 014$ & $1.957(2)$ & & $\mathrm{O} 17$ & $1.971(2)$ & & O5 & $1.969(2)$ \\
\hline & $2 \times \mathrm{O} 2$ & $1.967(2)$ & & $\mathrm{O} 10$ & $1.972(2)$ & & $\mathrm{O} 7$ & $1.971(2)$ \\
\hline & $2 \times 011$ & $1.972(2)$ & & & & & & \\
\hline & & & Ge4 & O5 & $1.736(2)$ & Ge7 & $\mathrm{O} 28$ & $1.729(1)$ \\
\hline \multirow[t]{5}{*}{ Ge1 } & O9 & $1.726(2)$ & & $\mathrm{O} 10$ & $1.738(2)$ & & $\mathrm{O} 24$ & $1.730(2)$ \\
\hline & $\mathrm{O} 20$ & $1.729(2)$ & & $\mathrm{O} 18$ & $1.745(1)$ & & $\mathrm{O} 3$ & $1.736(2)$ \\
\hline & $\mathrm{O} 26$ & $1.746(2)$ & & $\mathrm{O} 26$ & $1.755(2)$ & & $\mathrm{O} 25$ & $1.757(2)$ \\
\hline & O16 & $1.757(2)$ & & & & & & \\
\hline & & & & O15 & $1.724(2)$ & Ge8 & $\mathrm{O} 17$ & $1.737(2)$ \\
\hline \multirow[t]{5}{*}{$\mathrm{Ge} 2$} & $\mathrm{O} 14$ & $1.726(2)$ & & $\mathrm{O} 12$ & $1.739(2)$ & & $\mathrm{O} 2$ & $1.738(2)$ \\
\hline & O6 & $1.736(2)$ & & $\mathrm{O} 22$ & $1.752(2)$ & & O13 & $1.739(2)$ \\
\hline & $\mathrm{O} 25$ & $1.745(2)$ & & $\mathrm{O} 21$ & $1.754(2)$ & & $\mathrm{O} 27$ & $1.756(1)$ \\
\hline & $\mathrm{O} 27$ & & $1.757(2)$ & & & & & \\
\hline & & & Ge6 & O19 & $1.733(2)$ & Ge9 & O29 & $1.732(1)$ \\
\hline \multirow[t]{4}{*}{ Ge3 } & $\mathrm{O} 30$ & & $1.736(1)$ & $\mathrm{O} 23$ & $1.740(1)$ & & $\mathrm{O} 8$ & $1.733(2)$ \\
\hline & $\mathrm{O} 4$ & $1.738(2)$ & & O1 & $1.741(2)$ & & $\mathrm{O} 7$ & $1.736(2)$ \\
\hline & O11 & $1.739(2)$ & & $\mathrm{O} 16$ & $1.763(2)$ & & $\mathrm{O} 21$ & $1.766(2)$ \\
\hline & $\mathrm{O} 22$ & $1.752(2)$ & & & & & & \\
\hline
\end{tabular}

Consequently, two types of bridging oxygen atoms are encountered in this structure, either between two germanium atoms $(\mathrm{Ge}-\mathrm{O}-\mathrm{Ge})$ or between a germanium atom and antimony atom $(\mathrm{Ge}-\mathrm{O}-\mathrm{Sb})$. The space remaining between the polyhedra is occupied by cesium $\left(\mathrm{Cs}^{+}\right.$ ions) which are surrounded by oxygen neighbors located beyond $3.04 \AA$ (either 7 or 13 for the only distances shorter than $3.80 \AA$ ). The tilt in the orientation of the polyhedra along the $c$ direction, easily visible for the $\mathrm{SbO}_{6}$ octahedra with the structure projection on (101) plane given in Figure 1b, accounts for the superstructure mentioned above. 


\subsection{Optical characterization.}

The FT-IR spectrum over the range $450-1100 \mathrm{~cm}^{-1}$ and the Raman spectrum over the range $100-1100 \mathrm{~cm}^{-1}$ both registered for $\mathrm{CsSbGe}_{3} \mathrm{O}_{9}$ at room temperature are given in Figures $2 \mathrm{a}$ and $2 \mathrm{~b}$, respectively.
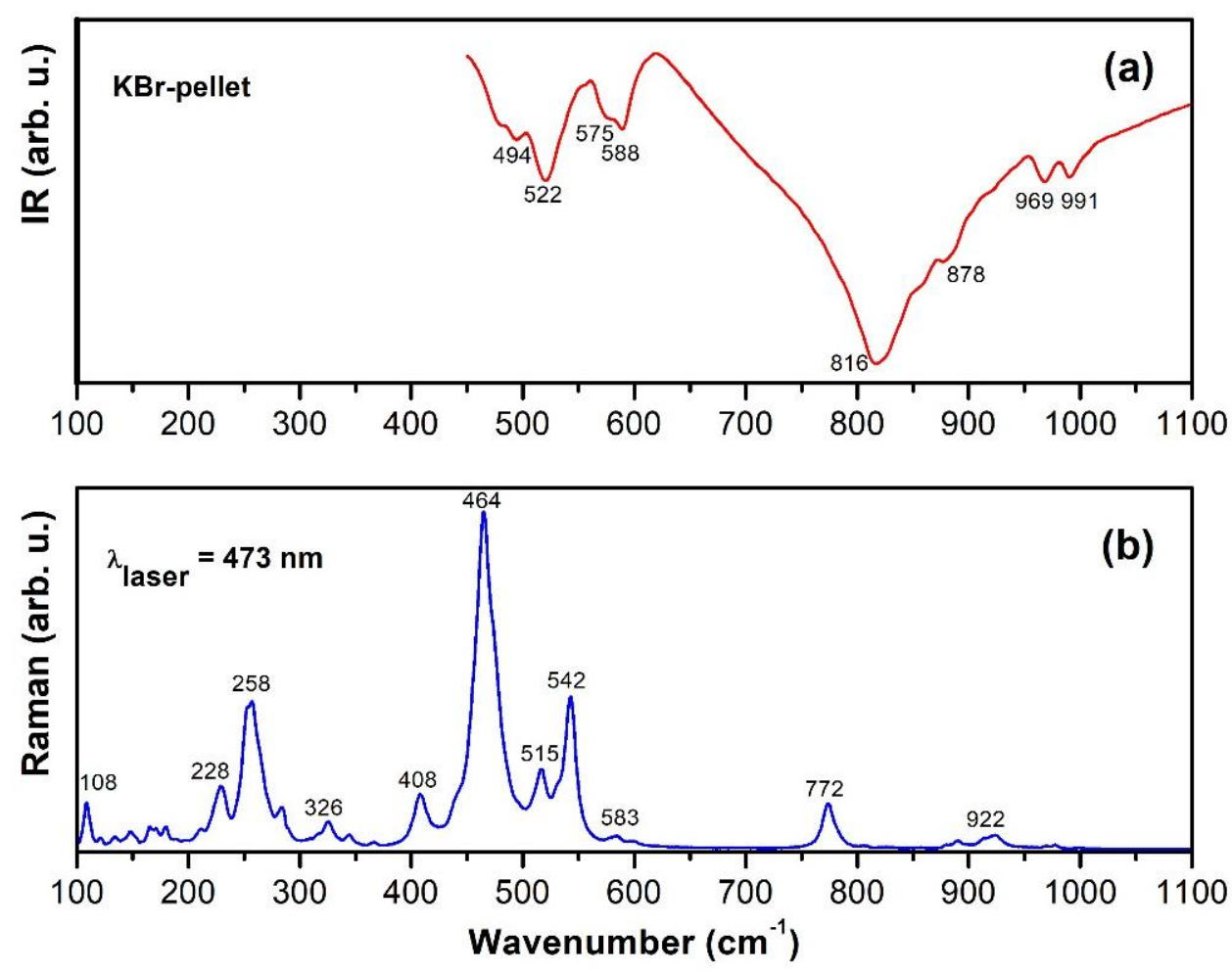

Figure 2. Non-polarized infrared transmission (a) and Raman (b) spectra registered at room temperature for $\mathrm{CsSbGe}_{3} \mathrm{O}_{9}$. Frequency positions are only given for the main bands.

The main factors that are responsible for the features of the spectra are the vibrations of both $\mathrm{GeO}_{4}$ tetrahedra and $\mathrm{SbO}_{6}$ coordinated groups, the deviation of these polyhedra away from the perfect $T_{d}$ and $\mathrm{O}_{h}$ symmetry, and the interactions between groups in the unit cell. The vibration modes can be assigned to movements of the $\mathrm{GeO}_{4}$ tetrahedra and lattice modes including motions of $\mathrm{Sb}^{V}$ in its octahedral coordination.

Classically, the Raman and infrared modes in the range of $600-1000 \mathrm{~cm}^{-1}$ are assigned in this structure to the $v(\mathrm{Ge}-\mathrm{O})$ stretching motions of both the $\mathrm{GeO}_{4}$ tetrahedra and their 
interconnecting $\mathrm{Ge}-\mathrm{O}-\mathrm{Ge}$ bridges. The bending vibrations of $\mathrm{GeO}_{4}$ groups and $\mathrm{Ge}-\mathrm{O}-\mathrm{Ge}$ bridges are expected at lower frequencies ${ }^{21,22}$. The stretching vibration modes of the $\mathrm{SbO}_{6}$ octahedra are encountered in the wavenumber range $450-850 \mathrm{~cm}^{-1}$ while both symmetric and antisymmetric bending vibration modes of the octahedral units are observed in the wavenumber range $250-600 \mathrm{~cm}^{-1} 23-26$. Despite the occurrence of mode-coupling and modemixing which hardens the separation of lattice modes that involves the $\mathrm{Sb}$ and Ge units, the oxygen bending motion in $\mathrm{SbO}_{6}$ octahedra should be observed in the $400-500 \mathrm{~cm}^{-1}$ domain. At this stage, polarized Raman experimental data associated with theoretical calculations would be greatly helpful to go further in the identification and assignment of vibrational modes in the entire $50-1000 \mathrm{~cm}^{-1}$ domain for $\mathrm{CsSbGe}_{3} \mathrm{O}_{9}$.

\section{Discussion}

A more in-depth analysis of the structure of the new compound $\mathrm{CsSbGe}_{3} \mathrm{O}_{9}$ deserves to be carried out in the light of the structures previously determined for the iso-formulated compounds $A \mathrm{SbGe}_{3} \mathrm{O}_{9}(A=\mathrm{K}, \mathrm{Rb})^{5,6}$. Although there is a metric parentage for the lattices, important differences in the structural arrangements must be underlined. Moreover, a general comparison of this compound family with other types of germanate structures seems useful.

\subsection{Structural hierarchy in the $\mathrm{ASbGe}_{3} \mathrm{O}_{9}$ family.}

It is interesting to examine comparatively the structural arrangements within the antimonygermanate family $A \mathrm{SbGe}_{3} \mathrm{O}_{9}(A=\mathrm{K}, \mathrm{Rb}, \mathrm{Cs})$. The tendency towards the highest symmetry (principle of symmetry) is often mentioned as a goal to be achieved for crystalline solids, so the relation of symmetry that exists between their structures is worth investigating ${ }^{35,36}$. In addition to the strictly geometry-based analysis of the atomic arrangements, they can be described including the relationship between their respective space groups. This can be shown graphically with a tree of group-subgroup relations $35-37$. 
The compound $\mathrm{KSbGe}_{3} \mathrm{O}_{9}$ is described within the hexagonal symmetry and adopts the Benitoite-type structure. It crystallizes in the non-centrosymmetric space group $P \overline{\mathbf{6}} c 2$ with lattice dimensions $a=6.94$ and $c=9.99 \AA\left(V=419 \AA^{3}\right)$ (5). Also displaying a noncentrosymmetric structure, $\mathrm{RbSbGe}_{3} \mathrm{O}_{9}$ conforms to the lower $P 31 c$ trigonal symmetry in a three times larger lattice, $3 \times V$, with $a=12.14$ and $c=9.96 \AA$ (6). This supercell can be obtained from the basic cell of $\mathrm{KSbGe}_{3} \mathrm{O}_{9}$ by applying the transformation operation $\left(\begin{array}{llll}1 & \overline{\mathbf{1}} & 0 & 1\end{array}\right.$ $20001)$ as shown in Figure 3.

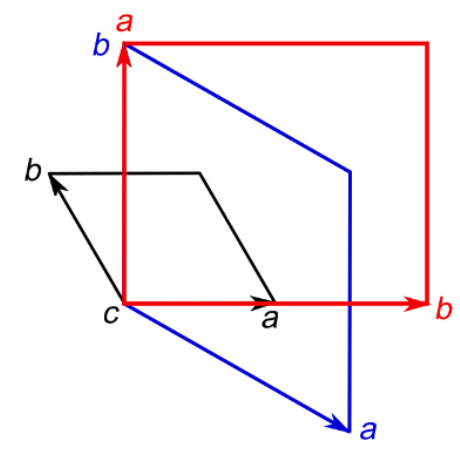

Figure 3. Metric relationships between the $\mathrm{KSbGe}_{3} \mathrm{O}_{9}$ hexagonal base cell ( $V$, black) and the $\mathrm{RbSbGe}_{3} \mathrm{O}_{9}$ trigonal $(3 \times V$, blue $)$ and $\mathrm{CsSbGe}_{3} \mathrm{O}_{9}$ orthorhombic $(3 \times c, 12 \times V$, red $)$ supercells.

By looking now at the symmetry, the trigonal structure of the Rb-germanate can be considered to derive from that of the K-germanate, itself from $P 6_{3} / m c m$ supergroup as represented in Figure 4. This diagram illustrates the reduction in symmetry of the space group from a highly symmetrical structure-type or "aristotype". In the case of germanate materials studied here, the symmetry $P 6_{3} / \mathrm{mcm}$ is the highest symmetry for which, to our knowledge, no experimental example has been found up to now. Starting from $P 6_{3} / m c m$, the first translationengleiche transition of index 2 leads to $P \overline{6} c 2$, then the unit cell is enlarged through a klassengleiche transition of index 3 (cell volume multiplied by 3 ) to $P \overline{6} 2 c$, and finally a second translationengleiche transition of index 2 leads to the symmetry P31c. This correlation 
path passing through the structure of $\mathrm{KSbGe}_{3} \mathrm{O}_{9}$ towards that of $\mathrm{RbSbGe}_{3} \mathrm{O}_{9}$ establishes a symmetry relationship of the group-subgroup type which allows to refer to a structural hierarchy even it includes a step for which no example is known.

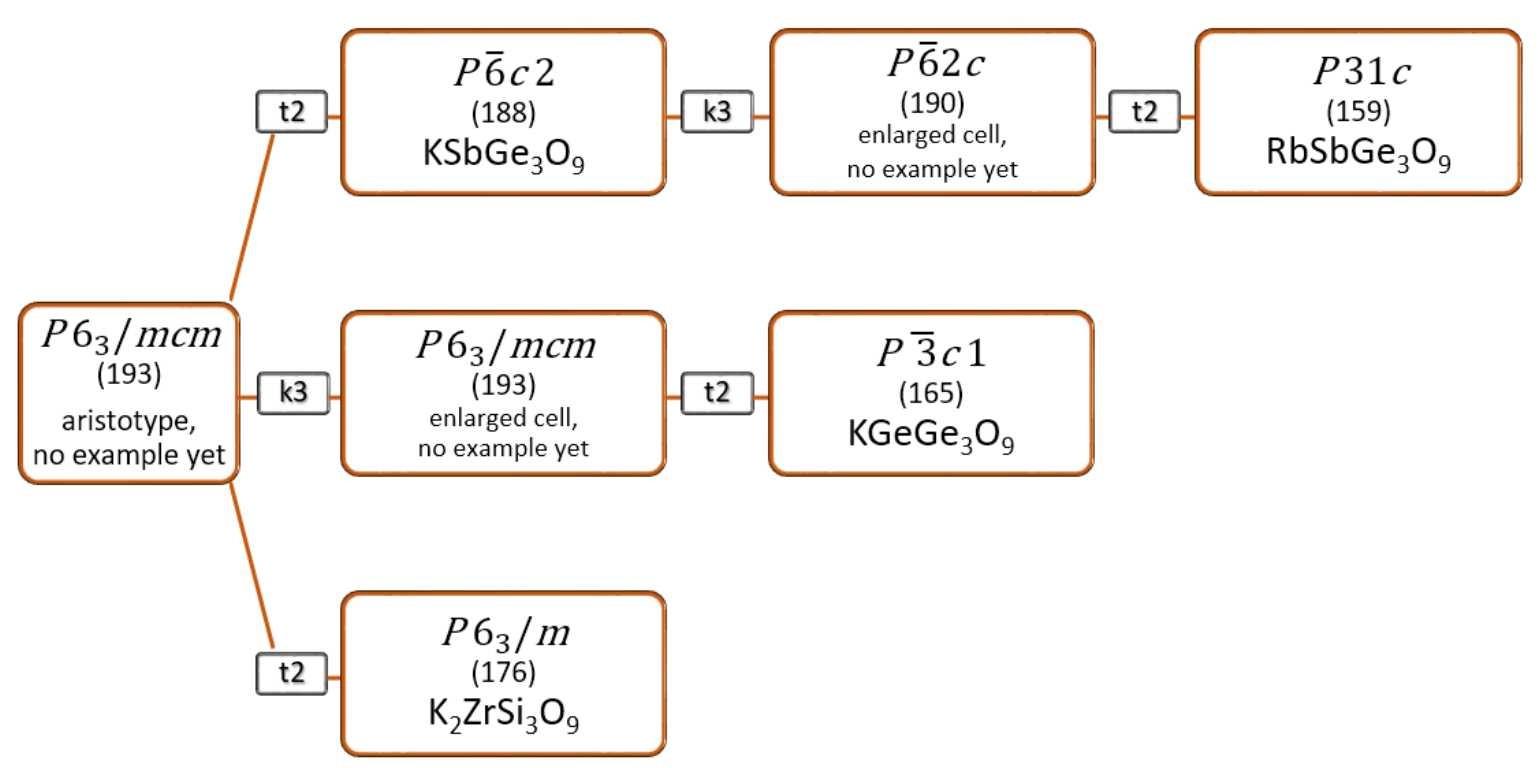

Figure 4. Group-subgroup scheme in the Bärnighausen formalism mentioning klassengleiche $(\mathrm{k})$ and translationengleiche $(\mathrm{t})$ indices, symmetry and unit cell transformations.

The structure of $\mathrm{CsSbGe}_{3} \mathrm{O}_{9}$ given here in the orthorhombic space group Pnma (see $\S 3.2$ ), is indicative of a further lowering in symmetry. With $a=12.36, b=13.85, c=31.48 \AA$, the supercell $(12 \times V)$ of $\mathrm{CsSbGe}_{3} \mathrm{O}_{9}$ can be obtained from the basic cell of $\mathrm{KSbGe}_{3} \mathrm{O}_{9}$ by applying the (1 $2202200000 \overline{3})$ transformation matrix (Figure 3).

In this case, it is not so easy to establish a relation to formalize this new decrease in symmetry from the trigonal $\mathrm{Rb}$ - to the orthorhombic Cs-germanate, especially since the atomic arrangements are also very different (rings $v s$. chains). It may therefore be inappropriate to speak here of a hierarchical relationship and preferable to see only a metric relationship between unit cells. 
The structures of the $A \mathrm{SbGe}_{3} \mathrm{O}_{9}(A=\mathrm{K}, \mathrm{Rb}, \mathrm{Cs})$ room temperature phases are built up with the same type of polyhedra $\left(\mathrm{GeO}_{4}\right.$ tetrahedra and $\mathrm{SbO}_{6}$ octahedra) assembled in a 3-D openframework displaying large channels. In the structures of compounds with $A=\mathrm{K}$ and $\mathrm{Rb}$, a sort of oligomerization of $\mathrm{GeO}_{4}$ tetrahedra should be mentioned with the existence of trimeric units $\left(\mathrm{Ge}_{3} \mathrm{O}_{9}\right)^{6-}$, Figure 5. These trimers can be viewed as a central $\mathrm{Ge}_{3} \mathrm{O}_{3}$ ring, perfectly planar in the hexagonal structure of $\mathrm{KSbGe}_{3} \mathrm{O}_{9}$ (5), with six outwardly directed $\mathrm{Ge}-\mathrm{O}$ bonds on each side of the mean plane of the ring (approximately the $a b$ plane).

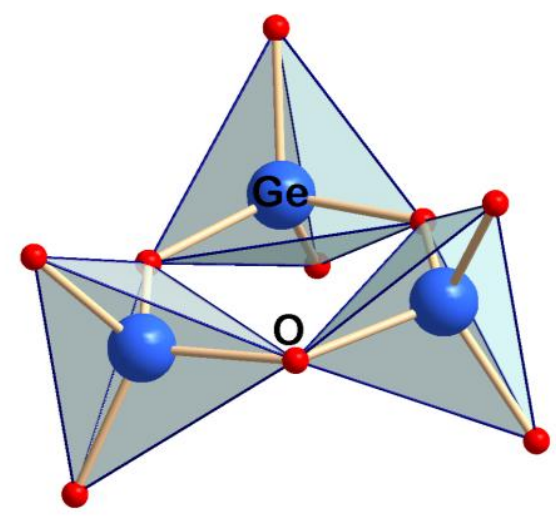

Figure 5. The $\left(\mathrm{Ge}_{3} \mathrm{O}_{9}\right)^{6-}$ trimer with its $\mathrm{Ge}_{3} \mathrm{O}_{3}$ central-ring and its six $\mathrm{Ge}-\mathrm{O}$ external bonds.

Even if the $\mathrm{K}$ - and Rb-structures are similar by the general organization of the polyhedra, some distortions occur in $\mathrm{RbSbGe}_{3} \mathrm{O}_{9}(3 \times V)$ which no longer complies with the hexagonal symmetry and thus, with the Benitoite type. In the hexagonal $P \overline{\mathbf{6}} c 2$ structure, $1 \times$ Ge and $1 \times$ $\mathrm{O}$ atoms located on special positions $6 k\left(\begin{array}{lll}x & y & 1 / 4\end{array}\right)$ form planar rings on mirror planes perpendicular to the hexagonal axis (Figure 6, left). Instead, central rings in the trigonal $P 31 c$ structure involve $3 \times \mathrm{Ge}$ and $3 \times \mathrm{O}$ placed at general independent positions $6 c\left(\begin{array}{lll}x & y & z\end{array}\right)$, so that their $z$-coordinate can move out of the plane $z=1 / 4$ and cause distortions of the ring (Figure 6 , right). 

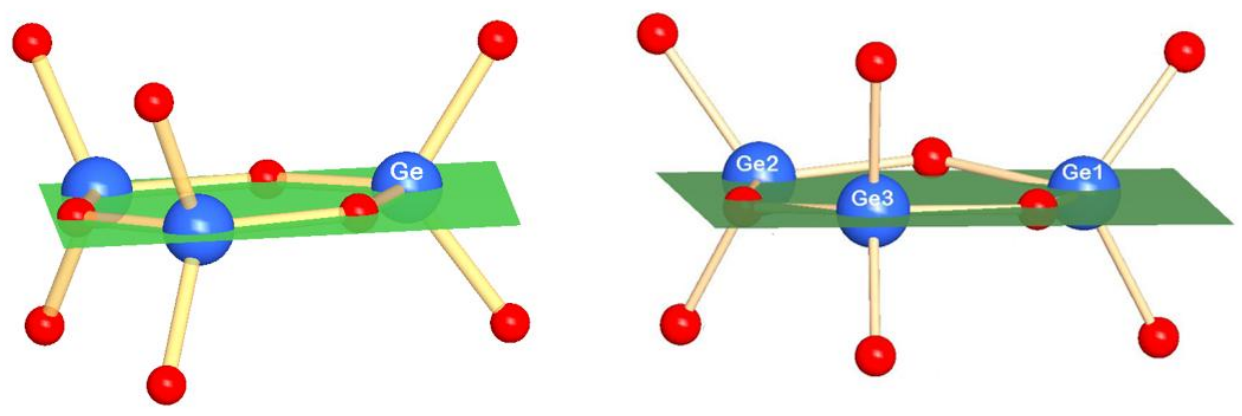

Figure 6. Geometry of the $\mathrm{Ge}_{3} \mathrm{O}_{3}$ central ring with respect to the mean plane constructed with the atoms of the ring ( $\approx a b$ plane): left-planar in $\mathrm{KSbGe}_{3} \mathrm{O}_{9}$, right-twisted in $\mathrm{RbSbGe}_{3} \mathrm{O}_{9}$.

The deviation from flatness of the $\mathrm{Ge}_{3} \mathrm{O}_{3}$ central-ring in the $\mathrm{Rb}$-compound typically reflects this symmetry lowering which allows twists in the position of the $\mathrm{GeO}_{4}$ units and modifications in the $\mathrm{Ge}-\mathrm{O}-\mathrm{Ge}$ angles ${ }^{6}$. Though built up with the same polyhedral units $\mathrm{SbO}_{6}$ and $\mathrm{GeO}_{4}$, the structure of $\mathrm{CsSbGe}_{3} \mathrm{O}_{9}(12 \times V)$ stands out from those of compounds with $A=$ $\mathrm{K}$ and $\mathrm{Rb}$. As substantial changes take place in the organization of these polyhedra in $\mathrm{CsSbGe}_{3} \mathrm{O}_{9}$, it is therefore that only a metric relationship exists between its lattice parameters and those of the other two compounds. The polyhedra still share all their vertices, the $\mathrm{SbO}_{6}$ with six tetrahedra and the $\mathrm{GeO}_{4}$ with two tetrahedra and two octahedra, but there is no more $\left(\mathrm{Ge}_{3} \mathrm{O}_{9}\right)$ oligomer. The arrangement of polyhedra within the unit cell is rather regular but variations in their orientation along the $c$-axis, Figure 1 , account for the large dimension of this lattice parameter. The structure of $\mathrm{CsSbGe}_{3} \mathrm{O}_{9}$ is characterized by one-dimensional chains of $\mathrm{GeO}_{4}$ tetrahedra, roughly aligned along the $b$-axis of the orthorhombic lattice, Figure 7 , and cross-linked along the $c$-axis through $\mathrm{SbO}_{6}$ octahedra, Figure 1. 


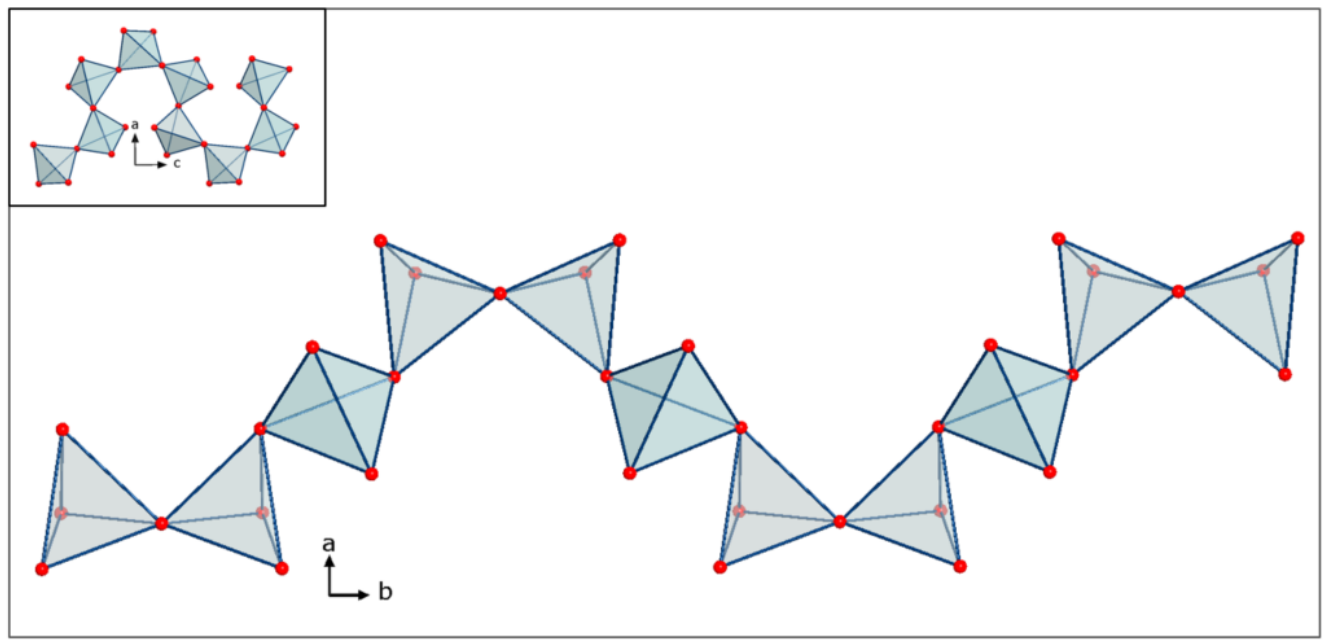

Figure 7. The infinite chains of $\mathrm{GeO}_{4}$ tetrahedra in $\mathrm{CsSbGe}_{3} \mathrm{O}_{9}$ (inset in $\mathrm{LiGeGe}_{3} \mathrm{O}_{9}{ }^{27}$ ).

\subsection{The $\mathrm{ASbGe}_{3} \mathrm{O}_{9}$ compounds amongst germanate materials.}

To place the discussion in a more general context, let us compare the $A \mathrm{SbGe}_{3} \mathrm{O}_{9}$ compounds with the germanate family of formula $A_{2} \mathrm{Ge}_{4} \mathrm{O}_{9}{ }^{27,28}$. On the strict basis of their formula, the $A_{2} \mathrm{Ge}_{4} \mathrm{O}_{9}$ compounds, or else $A_{2} \mathrm{GeGe}_{3} \mathrm{O}_{9}$, must be considered with a higher alkaline content than $A \mathrm{SbGe}_{3} \mathrm{O}_{9}$ in which the formal replacement of $\mathrm{Sb}^{V}$ by $\mathrm{Ge}^{I V}$ would lead to $A \mathrm{GeGe}_{3} \mathrm{O}_{9}$. However, since both $A_{2} \mathrm{GeGe}_{3} \mathrm{O}_{9}$ and $A \mathrm{SbGe}_{3} \mathrm{O}_{9}$ structures consist of tetrahedral-octahedral three-dimensional open-frameworks where the alkaline cations are hosted in voids between the polyhedra, the comparison can be further continued. The symmetry relationships that connect these compounds (space groups deriving from a common supergroup) are shown in Figure 4. Most $A_{2} \mathrm{GeGe}_{3} \mathrm{O}_{9}$ structures also contain three-membered units $\left(\mathrm{Ge}_{3} \mathrm{O}_{9}\right)^{6-}$ connected through isolated $\mathrm{GeO}_{6}$ octahedra ${ }^{28}$, similarly as found in the $A \operatorname{SbGe}_{3} \mathrm{O}_{9}(A=\mathrm{K}, \mathrm{Rb})$ structures via $\mathrm{SbO}_{6}$ octahedra ${ }^{5,6}$, Figures $8 \mathrm{e}$ and $8 \mathrm{f}$. This is the case of compounds $A_{2} \mathrm{GeGe}_{3} \mathrm{O}_{9}$ that are formed with the alkaline elements $\mathrm{Na}, \mathrm{K}$, and $\mathrm{Rb}^{28}$ and crystallize in the trigonal $P \overline{3} c 1$ symmetry. Instead, $\mathrm{CsSbGe}_{3} \mathrm{O}_{9}$ displays the orthorhombic symmetry (Figure $8 \mathrm{~g})$, and its structural resemblance with $\mathrm{Li}_{2} \mathrm{GeGe}_{3} \mathrm{O}_{9}\left(P 2_{1} c a\right.$, Figure 8a), recently described for 
ferroelectric behavior, deserves to be reported ${ }^{27}$. The infinite chains of $\mathrm{GeO}_{4}$ tetrahedra are corrugated (wrinkle), cross-linked by $\mathrm{SbO}_{6}$ octahedra in $\mathrm{CsSbGe}_{3} \mathrm{O}_{9}$, and they are "crumpled crankshaft-like", and interconnected via $\mathrm{GeO}_{6}$ octahedra in $\mathrm{Li}_{2} \mathrm{GeGe}_{3} \mathrm{O}_{9}$, see inset in Figure 7. Thus, the crystal symmetry increases $\left(P 2_{1} c a \rightarrow \mathrm{P} \overline{3} 1 c\right)$ in $A_{2} \mathrm{GeGe}_{3} \mathrm{O}_{9}{ }^{27,28}$ with the size of the alkaline cation from $\mathrm{Li}^{+}$to $\mathrm{Na}^{+}, \mathrm{K}^{+}$or $\mathrm{Rb}^{+}$and, on the contrary, decreases from $P \overline{\mathbf{6}} 2 c$ to $P 31 \mathrm{c}$ and next to Pnma (see $\S 3.2$ ) in the $A \mathrm{SbGe}_{3} \mathrm{O}_{9}$ family by changing $\mathrm{K}^{+}$by $\mathrm{Rb}^{+}$then by $\mathrm{Cs}^{+}$. The first step in lowering the symmetry, from hexagonal to trigonal, is associated with the disappearance of planarity for the $\mathrm{Ge}_{3} \mathrm{O}_{3}$ central ring.

Looking along the $c$-axis, two layers of octahedra and two layers of tetrahedra are alternately stacked in the trigonal lattices of $\mathrm{RbSbGe}_{3} \mathrm{O}_{9}$ (6) and $A_{2} \mathrm{GeGe}_{3} \mathrm{O}_{9}(A=\mathrm{Na}, \mathrm{K}, \mathrm{Rb})$ tetragermanates ${ }^{28,29}$. Likewise, the hexagonal unit cell of the Benitoite-type $\mathrm{KSbGe}_{3} \mathrm{O}_{9}$ structure ${ }^{5}$ contains two distinct layers of $\left(\mathrm{Ge}_{3} \mathrm{O}_{9}\right)^{6-}$ oligomers with $\mathrm{Ge}_{3} \mathrm{O}_{3}$ rings. However, the $\mathrm{A}_{2} \mathrm{GeGe}_{3} \mathrm{O}_{9}$ structure differs from those of $A \mathrm{SbGe}_{3} \mathrm{O}_{9}$ compounds by an offset of these layers perpendicular to the $c$-axis, so that the $\mathrm{Ge}_{3} \mathrm{O}_{3}$ rings from two successive layers no longer overlap $^{10,29}$ as shown in the structure projections, Figure $8 \mathrm{~b}$.

At this stage, an analogy with the Wadeite structure has also to be pointed out. This structure may be placed on a new branch of the group-subgroup tree given in Figure 4 as it also results from the highest $P 6_{3} / \mathrm{mcm}$ symmetry through a $\mathrm{t} 2$ translationengleiche. This natural silicate, $\mathrm{K}_{2} \mathrm{ZrSi}_{3} \mathrm{O}_{9}$, displays layers based on trimeric units of $\mathrm{SiO}_{4}$ tetrahedra, connected via $\mathrm{ZrO}_{6}$ octahedra, Figure $8 \mathrm{~d}^{30}$. The successive layers of tetrahedra are also staggered, such as the $\mathrm{Si}_{3} \mathrm{O}_{3}$ central rings do not overlap, but rings are planar in agreement with the $P 6_{3} / m$ hexagonal symmetry of the Wadeite structure ${ }^{28-30}$. To our knowledge, no germanate has been reported to date with this structure. On the contrary, several germanates and silicates containing cyclic trimers $\mathrm{X}_{3} \mathrm{O}_{9}(\mathrm{X}=\mathrm{Si}, \mathrm{Ge})$ have been described either within the $\mathrm{BaTiSi}_{3} \mathrm{O}_{9}$ Benitoite-type structure or within the $\mathrm{BaGeGe}_{3} \mathrm{O}_{9}$ tetragermanate structural type ${ }^{5,10,28,29}$. As shown in 
Figures $8 \mathrm{c}$ and $8 \mathrm{e}$, these structural types bear very strong resemblances, and details about their relationships can be found in earlier works $10,14,31,32$. These structures highly depend on the relative size of the constituting elements as reported particularly for the $A \mathrm{GeX}_{3} \mathrm{O}_{9}(\mathrm{~A}=\mathrm{Ba}$ and $\mathrm{X}=\mathrm{Si}, \mathrm{Ge}$ ) family where the geometrical ratio of the ionic radii of $\mathrm{B}$ and $\mathrm{X}$ has been stated to condition the relative stability of the structures ${ }^{10}$.

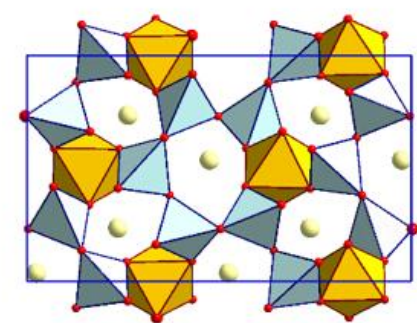

a

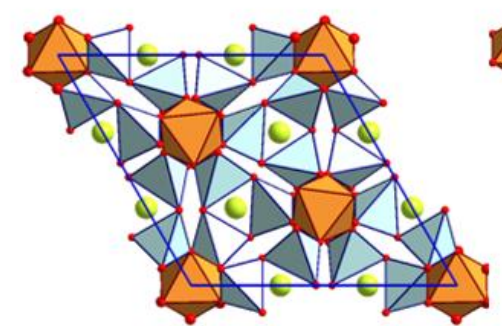

$b$

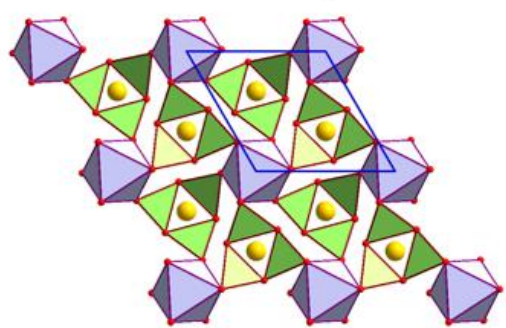

$d$

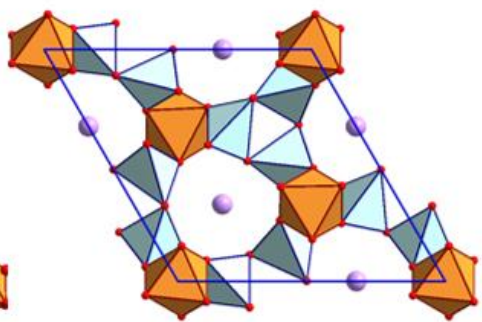

$c$
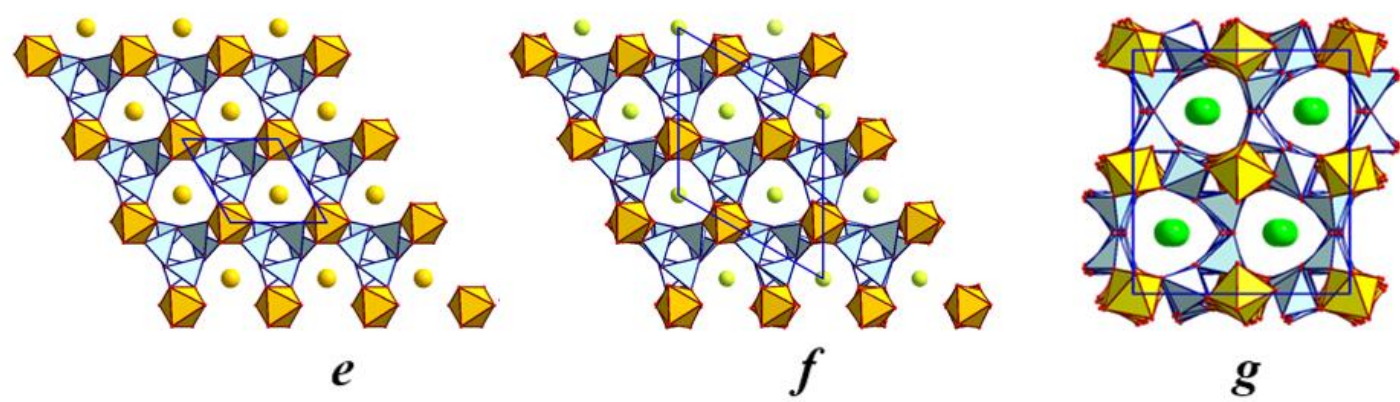

Figure 8. Various structures built with $\mathrm{XO}_{6}$ octahedra (brown), $\mathrm{MO}_{4}$ tetrahedra (blue) and electropositive cations (yellow, green or violet). $\boldsymbol{a}-\mathrm{Li}_{2} \mathrm{GeGe}_{3} \mathrm{O}_{9}$ (orthorhombic ${ }^{27}, P 2_{1} c a$, (101) projection), $\boldsymbol{b}-A_{2} \mathrm{GeGe}_{3} \mathrm{O}_{9} A=\mathrm{Na}, \mathrm{K}, \mathrm{Rb}$ (trigonal ${ }^{28}, P \overline{3} c 1$ ), $\boldsymbol{c}-\mathrm{BaGeGe}_{3} \mathrm{O}_{9}$ (trigonal ${ }^{11,32}, P 321$ ), $\boldsymbol{d}-\mathrm{K}_{2} \mathrm{ZrSi}_{3} \mathrm{O}_{9}$ Wadeite-type ${ }^{30,33}$ (hexagonal, $P 6_{3} / m$ ), $\boldsymbol{e}-\mathrm{KSbGe}_{3} \mathrm{O}_{9}$ (hexagonal ${ }^{5}$, $P \overline{6} c 2$, Benitoite-type), $\boldsymbol{f}$ - $\mathrm{RbSbGe}_{3} \mathrm{O}_{9}$ (trigonal ${ }^{6}, P 31 c$ ), $\boldsymbol{g}$ - $\mathrm{CsSbGe}_{3} \mathrm{O}_{9}$ (orthorhombic, (110)

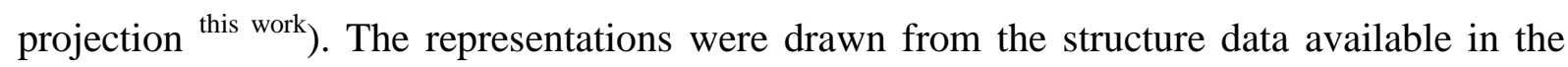
literature. 


\subsection{Local structural aspects.}

Although the geometry of the $\mathrm{SbO}_{6}$ and $\mathrm{GeO}_{4}$ polyhedra deviates respectively from the ideal $\mathrm{O}_{\mathrm{h}}$ and $\mathrm{T}_{\mathrm{d}}$ symmetry, the mean distances remain close to $1.95 \AA$ for $\mathrm{Sb}-\mathrm{O}$ and $1.74 \AA$ for $\mathrm{Ge}-$ $\mathrm{O}$ along with the $A \mathrm{SbGe}_{3} \mathrm{O}_{9}(A=\mathrm{K}, \mathrm{Rb}, \mathrm{Cs})$ family. In the compounds with $A=\mathrm{K}$ or $\mathrm{Rb}$, the $\mathrm{Ge}-\mathrm{O}$ bonds in the $\mathrm{Ge}_{3} \mathrm{O}_{3}$ central rings are a little longer than the outwardly directed $\mathrm{Ge}-\mathrm{O}$ bonds towards $\mathrm{SbO}_{6}$ octahedra. In $\mathrm{KSbGe}_{3} \mathrm{O}_{9}$, these are atoms on a mirror plane $m$ (at $x y^{1 / 4}$ or $x$ y $3 / 4$ special positions) which form the $\mathrm{Ge}_{3} \mathrm{O}_{3}$ ring as in the Wadeite-type structure ${ }^{30,33}$. Instead, in $\mathrm{RbSbGe}_{3} \mathrm{O}_{9}$, the mean plane through the atoms of the central-ring (at general $x y z$ positions) is tilted by $2.6^{\circ}$ to the (001) plane, a value which remains rather weak compared to that in the $A_{2} \mathrm{GeGe}_{3} \mathrm{O}_{9}$ and $\mathrm{BaGeGe}_{3} \mathrm{O}_{9}$ structures. The $\mathrm{Ge}_{3} \mathrm{O}_{3}$ rings are distorted and tilted by $\sim 27^{\circ}$ in $\mathrm{BaGeGe}_{3} \mathrm{O}_{9}(11,32)$ and by $\sim 22-25^{\circ}$ in the $A_{2} \mathrm{Ge}_{4} \mathrm{O}_{9}(\mathrm{~A}=\mathrm{Na}, \mathrm{K}, \mathrm{Rb}, \mathrm{Tl}, \mathrm{Ag})$ tetragermanate structures ${ }^{8-12}$

Another way to evaluate the structural distortion is to measure the $\mathrm{Ge}-\mathrm{O}-\mathrm{Ge}$ angles inside the $\mathrm{Ge}_{3} \mathrm{O}_{3}$ rings. Reported in the range $123-129^{\circ}$ for the trigonal $A_{2} \mathrm{GeGe}_{3} \mathrm{O}_{9}$ compounds ${ }^{28,29,31}$, around $125^{\circ}$ in $\mathrm{BaGeGe}_{3} \mathrm{O}_{9}{ }^{11,32}$, the $\mathrm{Ge}-\mathrm{O}-\mathrm{Ge}$ angle is $110.7^{\circ}$ in $\mathrm{KSbGe}_{3} \mathrm{O}_{9}{ }^{5}$ and $109.6^{\circ}$ in $\mathrm{RbSbGe}_{3} \mathrm{O}_{9}{ }^{6}$, close to the ideal $\mathrm{T}_{\mathrm{d}}$ geometry. Note for comparison the $\mathrm{Si}-\mathrm{O}-\mathrm{Si}$ angle of $107.2^{\circ}$ in the Wadeite structure ${ }^{33}$. In other words, the distortions within the $\left(\mathrm{Ge}_{3} \mathrm{O}_{9}\right)^{6-}$ trimers and the subsequent changes in the $\mathrm{Ge}-\mathrm{O}-\mathrm{Ge}$ angles accommodate the size of the alkaline cations ${ }^{28}$. Accordingly, the angle values of $\mathrm{O}-\mathrm{Ge}-\mathrm{O}$ bridges between outwardly directed $\mathrm{Ge}-$ $\mathrm{O}$ bonds, ranging between $110^{\circ}$ and $112^{\circ}$, are lower than the corresponding angles measured close to $125^{\circ}$ in the tetragermanate structures ${ }^{28}$.

Regarding now the alkaline cations, they are enclosed in regular cages made of four trimers in the Wadeite-type structure. It has been specified that the enthalpies of formation become more exothermic with the size of the alkaline cation, thus the stability of the compound increases ${ }^{33}$. In the $A_{2} \mathrm{GeGe}_{3} \mathrm{O}_{9}$ and $\mathrm{BaGeGe}_{3} \mathrm{O}_{9}$ tetragermanates, the cation environment is less regular 
(i.e. with less uniform distribution of distances around the $A$ or $\mathrm{Ba}$ position) due to the twist and the tilt of the $\mathrm{Ge}_{3} \mathrm{O}_{3}$ rings. Conversely, in the $A \mathrm{SbGe}_{3} \mathrm{O}_{9}$ family, the most regular environment around the $A$ cation is observed for $\mathrm{KSbGe}_{3} \mathrm{O}_{9}$, where the overlapping of the $\mathrm{Ge}_{3} \mathrm{O}_{3}$ central rings allows the formation of channels. It becomes less regular for $A=\mathrm{Rb}$, due to the ring deformation (atoms slightly out of the $a b$ plane), and distorted in $\mathrm{CsSbGe}_{3} \mathrm{O}_{9}$, which still contains channels but no more three-membered cycles. The size, but also the polarizability, of the $A$ element present as a cation, is responsible for these structural modifications. The effective cationic radius increases from $\mathrm{K}^{+}$to $\mathrm{Rb}^{+}$and $\mathrm{Cs}^{+}(1.52,1.66$, and $1.81 \AA$ respectively for $C N 6$ environments ${ }^{34}$ ), and the polarizing power changes accordingly. Nevertheless, as $\mathrm{Cs}^{+}$cations are surrounded by 12 to 15 oxygen neighbors (between 3.2 and 4.1 $\AA$ ), it is preferable to consider the $C N 12$ value of $2.02 \AA$ for the ionic radius. Likely, the $A \mathrm{SbGe}_{3} \mathrm{O}_{9}$ homologs with $A=\mathrm{Li}$ or $\mathrm{Na}$ can never be obtained because the $\mathrm{Li}^{+}$and $\mathrm{Na}^{+}$cations are too small (ionic radii 0.90 and $1.16 \AA$ for $C N 6$, respectively) and too polarizing. On the contrary, the large and weakly polarizing $\mathrm{Cs}^{+}$cation, which lies at a distance of $3.04 \AA$ from its closest oxygen neighbors in $\mathrm{CsSbGe}_{3} \mathrm{O}_{9}$ (vs. $2.87-2.92 \AA$ for $\mathrm{K}^{+}$and $\mathrm{Rb}^{+5,6}$ ), provides the $\mathrm{GeO}_{4}$ units an additional degree of freedom to position themselves relative to the surrounding tetrahedra. Therefore, the $\mathrm{GeO}_{4}$ tetrahedra form chains ( along $b$-axis) interconnected through $\mathrm{SbO}_{6}$ octahedra within a 3-D framework with channels occurring along the $c$-axis, Figures 1 and 7.

Furthermore, bicyclic $\left(\mathrm{Ge}_{2} \mathrm{O}_{3}\right)_{2} \mathrm{Sb}$ units, Figure 9, are present in the orthorhombic $\mathrm{CsSbGe}_{3} \mathrm{O}_{9}$ structure and the mean plane through the atoms of the $\mathrm{SbGe}_{2} \mathrm{O}_{3}$ rings is almost the equatorial plane of the $\mathrm{SbO}_{6}$ octahedron. These units can be also formulated as $\mathrm{Sb}\left(\mathrm{Ge}_{2} \mathrm{O}_{3}\right)_{2} \mathrm{O}_{10}$ by taking into account the outward connections, $2 \times \mathrm{Sb}-\mathrm{O}$ and $8 \times \mathrm{Ge}-\mathrm{O}$. 


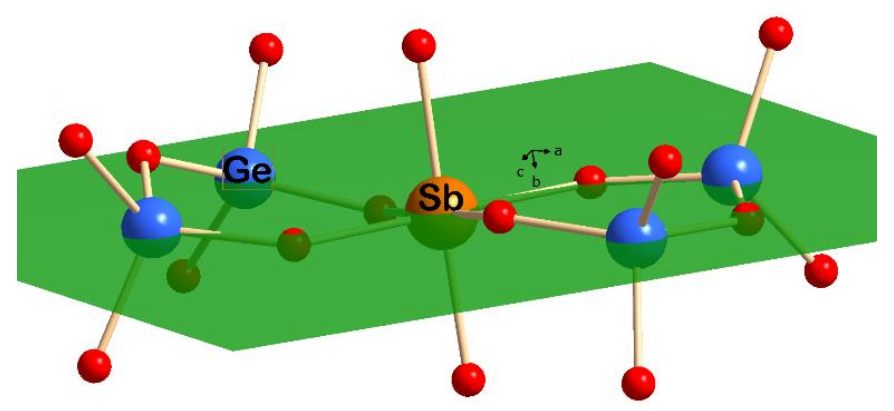

Figure 9. The bicyclic $\left(\mathrm{Ge}_{2} \mathrm{O}_{3}\right)_{2} \mathrm{Sb}$ units in the orthorhombic structure of $\mathrm{CsSbGe}_{3} \mathrm{O}_{9}$.

\subsection{Spectroscopic features.}

To close the discussion, let us return to the vibrational signature of $\mathrm{CsSbGe}_{3} \mathrm{O}_{9}$. Its IR and Raman spectra are different from the shape of the spectra obtained for both $\mathrm{KSbGe}_{3} \mathrm{O}_{9}$ and $\mathrm{RbSbGe}_{3} \mathrm{O}_{9}$ compounds, Figure 10.
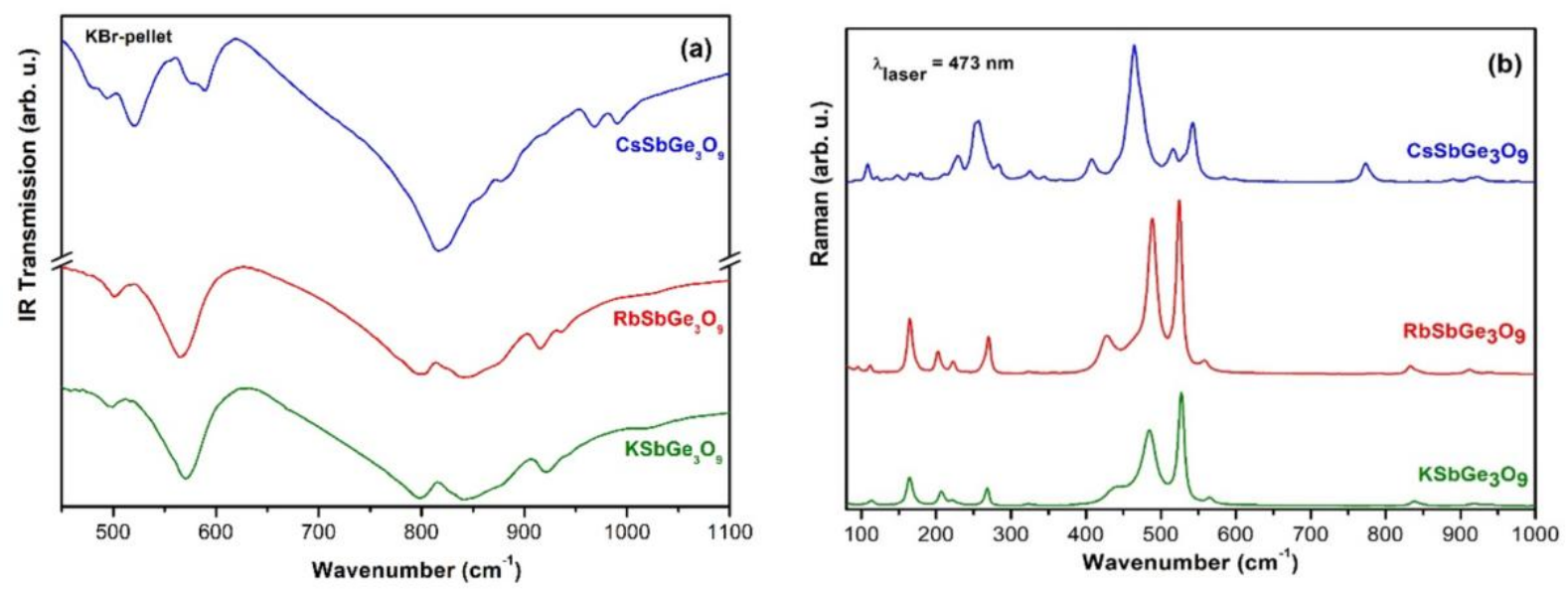

Figure 10. (a) IR and (b) Raman spectra recorded at room temperature for compounds of the $A \mathrm{SbGe}_{3} \mathrm{O}_{9}$ family, $A=\mathrm{K}, \mathrm{Rb}, \mathrm{Cs}$.

The 565 and $937 \mathrm{~cm}^{-1}$ frequency bands which are both IR and Raman active in $\mathrm{K}-$ and $\mathrm{Rb}$ phases, are respectively due to $\mathrm{Ge}-\mathrm{O}-\mathrm{Ge}$ intra-cycle bending motions and to $\mathrm{Ge}-\mathrm{O}$ symmetric stretching, both occurring in the $\mathrm{Ge}_{3} \mathrm{O}_{3}$ central-rings ${ }^{5}$. Both $\mathrm{O}$ and $\mathrm{Ge}$ atoms participate in 
these vibration modes. These typical bands attributed to the three-membered rings do not appear in the spectra of the Cs-compound, which agrees with the lack of rings in its structure. Other significant changes can be expected based on the structural differences noted along with the $A \mathrm{SbGe}_{3} \mathrm{O}_{9}$ series and related to both the arrangement and symmetry of the polyhedra. $\mathrm{A}$ broadening, or even a splitting, of the bands associated with bending or stretching vibration modes that involve $\mathrm{Ge}-\mathrm{O}-\mathrm{Ge}$ bridges, is expected for $\mathrm{CsSbGe}_{3} \mathrm{O}_{9}$ as the dispersion of the angular values from 105 to $156^{\circ}$ (average value of $133.5^{\circ}$ ) is slightly higher than in the

trigonal structures with $A=\mathrm{K}$ and $\mathrm{Rb}{ }^{5,6}$. Likewise, the $\mathrm{Ge}-\mathrm{O}-\mathrm{Sb}$ angles display a large dispersion in the range 121 to $136^{\circ}$ and their average value of $124.6^{\circ}$ greatly deviates from the average values of $\sim 134^{\circ}$ measured for the $\mathrm{K}$ - and $\mathrm{Rb}$ - compounds ${ }^{5,6}$.

The vibrational differences observed in the IR and Raman spectra of the compound $\mathrm{CsSbGe}_{3} \mathrm{O}_{9}$ and those with the same formula and $A=\mathrm{K}$ and $\mathrm{Rb}$ find their origin in all the structural specificities underlined above in the discussion part.

\section{Conclusion}

Transparent and colorless $\mathrm{CsSbGe}_{3} \mathrm{O}_{9}$ crystals have been spontaneously grown using a hightemperature flux method. No phase transition was observed up to their melting point detected at $1080^{\circ} \mathrm{C}$, which indicates good thermal stability in a large temperature range. The structure, determined from single-crystal X-ray diffraction data is most probably non-centrosymmetric despite our choice to report it in the centrosymmetric maximal supergroup Pnma. Physical characterizations as piezoelectric measurements could unambiguously answer this point as soon as $\mathrm{CsSbGe}_{3} \mathrm{O}_{9}$ single-crystals with a centimeter size could be obtained. The X-ray orthorhombic structure shows a 3-D open-framework built up of $\mathrm{GeO}_{4}$ tetrahedra and $\mathrm{SbO}_{6}$ distorted octahedra leading to inter-polyhedral Ge-O-Ge and Ge-O-Sb bridges. With infinite chains of regular tetrahedra $\mathrm{GeO}_{4}$, it highly differs from the structures of the iso-formulated $\mathrm{KSbGe}_{3} \mathrm{O}_{9}$ and $\mathrm{RbSbGe}_{3} \mathrm{O}_{9}$ compounds. The increase in the size of the element $A$ leads to a 
loss of crystal symmetry in the $A \mathrm{SbGe}_{3} \mathrm{O}_{9}$ family, from $P \overline{\mathbf{6}} c 2(\mathrm{~K})$ to $P 31 c(\mathrm{Rb})$, responsible for the disappearance of the $\mathrm{Ge}_{3} \mathrm{O}_{3}$ central-ring planarity, and from hexagonal/trigonal (K, $\mathrm{Rb})$ to orthorhombic $(\mathrm{Cs})$ which causes the disappearance of the $\left(\mathrm{Ge}_{3} \mathrm{O}_{9}\right)$ trimers. The structural analysis mainly based on geometrical features and supported by literature reports tends to prove that the nature of the alkaline cations and the relative size of the constitutive elements play a dominant role in the formation and the stability of these compounds.

\section{Acknowledgment}

The EDX experiments were conducted at the Plateau Technique Microscopie à Balayage at the IEM Institute in Montpellier, France. IR, Raman and DSC measurements were done at the Platform of Analysis and Characterization (PAC) of the Pôle Chimie Balard in Montpellier, France. The X-ray diffraction experiments were done using the X-ray and gamma-ray network of the technological resource of Univ. Montpellier, France.

\section{Supporting information}

Table gathering the main bond lengths and angles around $\mathrm{Sb}$ and $\mathrm{Ge}$ atoms in $\mathrm{CsSbGe}_{3} \mathrm{O}_{9}$.

\section{Funding information}

Funding for this research was provided by the French Ministry of Higher Education, Scientific Research and Innovation, and the French National Center of Scientific Research (CNRS). 


\section{REFERENCES}

(1) Lignie A., Ménaert B., Armand P., Peña A., Debray J., Papet P., Top-Seeded Solution Growth and Structural Characterizations of $\alpha$-Quartz-like Structure $\mathrm{GeO}_{2}$ Single Crystal, Cryst. Growth Des., 2013, 13 4220-4225.

(2) Papet P., Bath M., Haidoux A., Ruffle B., Menaert B., Peña A., Debray J., Armand P., High-temperature piezoelectric properties of flux-grown $\alpha-\mathrm{GeO}_{2}$ single crystal, J. Appl. Phys., 2019, 126, 144102.

(3) Hermet P., Fraysse G., Lignie A., Armand P., Papet P., Density Functional Theory Predictions of the Nonlinear Optical Properties in $\alpha$-Quartz-type Germanium Oxide, J. Phys. Chem. C, 2012, 116, 8692-8698.

(4) Lignie A., Granier D., Armand P., Haines J, Papet P., Modulation of quartz-like $\mathrm{GeO}_{2}$ structure by Si substitution: an X-ray diffraction study of $\mathrm{Ge}_{1-\mathrm{x}} \mathrm{Si}_{\mathrm{x}} \mathrm{O}_{2}(0 \leq \mathrm{x}<0.2)$ flux-grown single-crystals, J. Appl. Cryst., 2012, 45, 272-278.

(5) Armand P., Hermet P., Tillard M., Haidoux A., Granier D., The open-framework structure of $\mathrm{KSbGe}_{3} \mathrm{O}_{9}$ flux-grown crystals investigated by X-ray diffraction, vibrational spectroscopy, and DFT calculations, J. Solid State Chem., 2021, 295, 121925.

https://doi.org/10.1016/j.jssc.2020.121925

(6) Armand P., Tillard M., Haidoux A., Daenens L., Single-crystal growth, structure, and optical properties of a new non-centrosymmetric germanate, $\mathrm{RbSbGe}_{3} \mathrm{O}_{9}$, J. Solid State Chem., 2020, 286, 121290.

DOI: $10.1016 / \mathrm{j} . j s s c .2020 .121290$

(7) Zachariasen W. H., The Crystal Structure of Benitoite, BaTiSi ${ }_{3} \mathrm{O}_{9}$, Z. Kristallogr. Cryst. Mater., 1930, 74, 139-146.

(8) Choisnet J., Deschanvres A., Tarte P., Spectres vibrationnels des silicates et germanates renfermant des anneaux, $\mathrm{M}_{3} \mathrm{O}_{9}(\mathrm{M}=\mathrm{Si}, \mathrm{Ge})$-I. Attribution des fréquences caractéristiques de l'anneau $\mathrm{M}_{3} \mathrm{O}_{9}$ dans les composés de type bénitoïte, wadéite et tétragermanate, Spectrochim. Acta A, 1975, 31, 1023-1034.

(9) Choisnet J., Deschanvres A., Tarte P., Spectres vibrationnels des silicates et germanates renfermant des anneaux, $\mathrm{M}_{3} \mathrm{O}_{9} \quad(\mathrm{M}=\mathrm{Si}, \mathrm{Ge})$-II. Etude des spectres vibrationnels des silicogermanates de type bénitoïte: mise en évidence des anneaux mixtes $\left(\mathrm{GeSi}_{2} \mathrm{O}_{9}\right)$ et $\left(\mathrm{Ge}_{2} \mathrm{SiO}_{9}\right)$, Spectrochim. Acta A, 1976, 32, 57-66.

(10) Goreaud M., Choisnet J., Deschanvres A., Raveau B., Synthèse et évolution structurale de nouveaux silicogermanates $\mathrm{BaGe}\left(\mathrm{Ge}_{3-\mathrm{x}} \mathrm{Si}_{\mathrm{x}}\right) \mathrm{O}_{9}$ de type benitoïte et de structure apparentée, Mat. Res. Bull., 1973, 8, 1205-1214. 
(11) Robbins C., Perloff A., Block S., Crystal Structure of $\mathrm{BaGe}\left(\mathrm{Ge}_{3} \mathrm{O}_{9}\right)$ and its Relation to Benitoite, J. Res. Natl. Bur. Stand., 1966, 70A, 385-391.

(12) Takahashi Y., Iwasaki K., Masai H., Fujiwara T., Raman spectroscopic study of Benitoite-type compounds, J. Ceram. Soc. Jpn., 2008, 116, 1139-1142.

(13) Robbins C. R., The Compound $\mathrm{BaTiGe}_{3} \mathrm{O}_{9}$, J. Am. Ceram. Soc., 1960, 4311, 610-610. doi.org/10.1111/j.1151-2916.1960.tb13626.x

(14) Choisnet J., Deschanvres A., Raveau B., Sur de nouveaux germanates et silicates de type Bénitoïte, J. Solid State Chem., 1972, 4, 209-2018.

(15) APEX3. Version 2017.3-0, Bruker AXS, Inc., Madison, Wisconsin, USA, 2017.

(16) Sheldrick G. M., Crystal structure refinement with SHELXL, Acta Cryst. C, 2015, 71, 38.

DOI : $10.1107 /$ S2053229614024218

(17) Sheldrick G. M., SHELXT - Integrated space-group and crystal-structure determination, Acta Cryst. A, 2015, 71, 3-8.

DOI: $10.1107 / \mathrm{S} 2053273314026370$

(18) Degen T., Sadki M., Bron E., König U., Nénert G., The HighScore suite, Powder Diffr., 2014, 29(S2), S13-S18.

(19) http://www.ccdc.cam.ac.uk/conts/retrieving.html (or from the CCDC, 12 Union Road, Cambridge CB2 1EZ, UK; Fax: +44 1223 336033; E-mail: deposit@ccdc.cam.ac.uk).

(20) Putz H., Brandenburg GbR K., Diamond - Crystal and Molecular StructureVisualization, Crystal Impact, Kreuzherrenstr. 102, 53227 Bonn, Germany http://www.crystalimpact.com/diamond

(21) Fraysse G., Lignie A., Hermet P., Armand P., Bourgogne D., Haines J., Ménaert B., Papet P., Vibrational origin of the thermal stability in the highly distorted $\alpha$-quartz-type material $\mathrm{GeO}_{2}$, an experimental and theoretical study, Inorg. Chem., 2013, 52, 7271-7279.

DOI: $10.1021 /$ ic4009416

(22) Cavalli E., Zannoni E., Bettinelli M., Speghini A., Tonelli M., Toncelli A., Vibrational properties of $\mathrm{Ca}_{3} \mathrm{Sc}_{2} \mathrm{Ge}_{3} \mathrm{O}_{12}$, a garnet host crystal for laser applications, J. Phys.: Condens. Matter, 2000, 12, 4665- 4674.

(23) Charton P., Armand P., Glasses in the $\mathrm{TeO}_{2}-\mathrm{Sb}_{2} \mathrm{O}_{4}$ binary system, J. Non-Cryst. Solids, 2003, 316, 189-197. 
(24) Zhao H., Tan D., Tian Y., He Y., Li Y., Li X., Yang K., Chen B., Xiao W., Studies on Im-3-type $\mathrm{KSbO}_{3}$ using high-pressure X-ray diffraction and Raman spectroscopy, High Press. Res., 2018, 38, 232-242.

https://doi.org/10.1080/08957959.2018.1477941

(25) Carvalho Castro Jr M., Viana Carvalho E. F., Paraguassu W., Pedro Ayala A., Snyder F. C., Lufasod M. W., William de Araujo Paschoal C., Temperature-dependent Raman spectra of $\mathrm{Ba}_{2} \mathrm{BiSbO}_{6}$ ceramics, J. Raman Spectrosc., 2009, 40, 1205-1210.

DOI $10.1002 /$ jrs. 226

(26) R. L. Frost, S. Bahfenne, A Review of the Vibrational Spectroscopic Studies of Arsenite, Antimonite, and Antimonate Minerals, Appl. Spectrosc. Rev., 2010, 452, 101-129.

(27) Redhammer G.J., Tippelt G., The polar phase of $\mathrm{Li}_{2} \mathrm{Ge}_{4} \mathrm{O}_{9}$ at 298, 150, and 90 K, Acta Cryst. C, 2013, 69, 1091-1095.

(28) Redhammer G.J., Tippelt G., The tetragermanates $\mathrm{A}_{2} \mathrm{Ge}_{4} \mathrm{O}_{9}(\mathrm{~A}=\mathrm{Na}, \mathrm{K}$ and $\mathrm{Rb})$, Acta Cryst. C, 2013, 69, 995-1001

(29) Hazen R. M., Downs R. T., High-temperature and high-pressure crystal chemistry, Reviews in Mineralogy \& Geochemistry, Book 41, 2018, Eds Walter de Gruyter GmbH \& Co $\mathrm{KG}$

(30) Henshaw D. E., The structure of Wadeite, Mineral. Mag. J. Mineral. Soc., 1955, 30, 585595.

(31) Goreaud M., Raveau B., Structure Cristalline de $\mathrm{Rb}_{2} \mathrm{Ge}_{4} \mathrm{O}_{9}$ et $\mathrm{Rb}_{2} \mathrm{TiGe}_{3} \mathrm{O}_{9}$ de Type 'tetragermanate' et Etude Structurale Comparée de Germanates en Anneaux, Acta Cryst. B, 1976, 32, 1536.

(32) Shashkov A.Y., Rannev N.V., Venevtsev Y.N., Atomic Structure of Crystals of $\alpha-$ $\mathrm{PbGe}_{4} \mathrm{O}_{9}, \mathrm{BaGe}_{4} \mathrm{O}_{9}$, and $\mathrm{Pb}_{2 / 3} \mathrm{Sr}_{1 / 3} \mathrm{Ge}_{4} \mathrm{O}_{9}$ and Features of the Coordination of Germanium Atoms in Framework Tetragermanates, Sov. J. Coord. Chem., 1984, 10, 787-794.

(33) Xu H., Navrotsky A., Balmer M.L., Su Y., Crystal-chemical and energetic systematics of Wadeite-type phases $\mathrm{A}_{2} \mathrm{BSi}_{3} \mathrm{O}_{9}(\mathrm{~A}=\mathrm{K}, \mathrm{Cs} ; \mathrm{B}=\mathrm{Si}$, Ti, Zr), Phys. Chem. Miner., 2005, 32, 426-435.

(34) Shannon R.D., Revised Effective Ionic Radii and Systematic Studies of Interatomic Distances in Halides and Chalcogenides, Acta Cryst. A, 1976, 32, 751-767.

(35) Bärnighausen H., Group-subgroups relations between space groups: a useful tool in crystal chemistry MATCH, Commun. Math. Chem., 1980, 9, 139-175. 
(36) Müller U, Inorganic Structural Chemistry, ISBN 978-0-470-01865-8 Wiley, 2007 (37) Ivantchev, S., Kroumova, E., Madariaga, G., Pérez- Mato, J.M., Aroyo, SUBGROUPGRAPH: a computer program for analysis of group-subgroup relations between space groups, J. Appl. Cryst. 2000, 33, 1190-1191. 


\section{For Table of Contents Only}

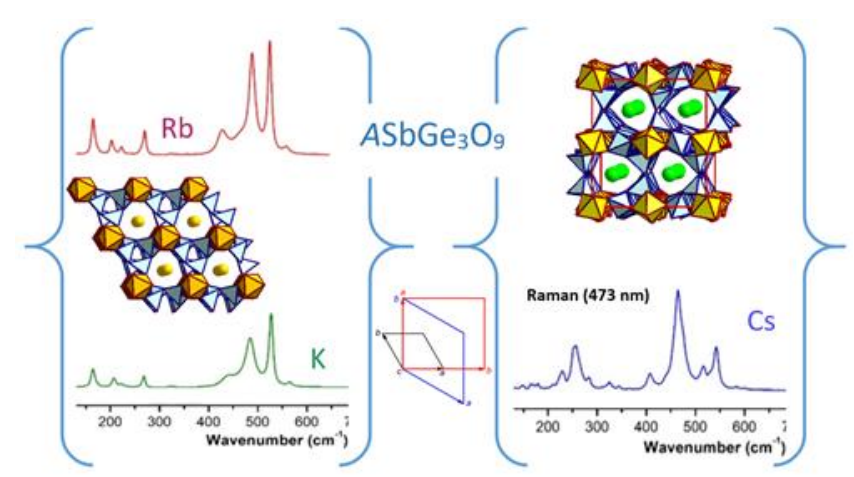

The germanate $\mathrm{CsSbGe}_{3} \mathrm{O}_{9}$, grown spontaneously from a high-temperature solution of $\mathrm{Cs}_{2} \mathrm{Mo}_{4} \mathrm{O}_{13}$ used as a flux, is characterized by X-ray diffraction and IR-Raman spectroscopies. Regular $\mathrm{GeO}_{4}$ tetrahedra and $\mathrm{SbO}_{6}$ octahedra arranged in a 3-D orthorhombic lattice leave channels hosting the $\mathrm{Cs}^{+}$cations. The structural evolution within the family $A \mathrm{SbGe}_{3} \mathrm{O}_{9}$ is discussed related to the literature and the nature of the monovalent alkaline cation $A(\mathrm{~K}, \mathrm{Rb}$, Cs). 